\title{
Uafhængighed gør det ikke alene - en evaluering af Den Uafhængige Politiklagemyndighed*
}

\author{
Af Lars Holmberg, Lektor i Kriminologi, \\ Kriminalistisk Institut, Københavns Universitet
}

\begin{abstract}
The present paper presents the main results of an evaluation of the Independent Police Complaints Authority in Denmark. Overall, the establishment of the new authority in 2012 does not seem to have had much impact on complainants' satisfaction: $73 \%$ are dissatisfied with the overall handling of their complaint. The majority recognizes the authority as being independent of the police, but the majority also believes that the handling of their case was biased in favour of the police. Whereas the focus of the Authority is to determine whether individual officers did something wrong, most complainants seem more interested in holding the police organization accountable. The paper suggests that mediation be tried as an alternative way of handling some complaints. So far, however, legal obstacles seem to make this impossible.
\end{abstract}

\section{Indledning}

Hvad er den overordnede opgave for et klagesystem, som behandler politiklager? Dette spørgsmål er helt centralt, når man skal vurdere, om Den Uafhængige Politiklagemyndighed (herefter Politiklagemyndigheden), som blev etableret i Danmark i 2012, har levet op til forventningerne. Som det vil fremgå, er der nemlig stor forskel på Politiklagemyndighedens officielle mål - upartisk undersøgelse og vurdering af klagernes indhold - og så de ønsker, hovedparten af de klagende har til klagebehandlingen. I mange tilfælde står den nøgterne vurdering af en klage nærmest i vejen for, at klageren oplever sin klage imødekommet.

I denne artikel ${ }^{1}$ rapporteres resultaterne af en evaluering af Politiklagemyndigheden, gennemført i 2015-16, og de mulige årsager til den store utilfredshed med Politiklagemyndigeden analyseres. Artiklen beskriver først baggrunden for etableringen af Politiklagemyndigheden og dernæst internationale erfaringer med

* Title in English: Independence doesn't do it alone: An evaluation of the Independent Police Complaints Authority. 
politiklagesystemer. Herefter gennemgås de vigtigste resultater af en evaluering af myndighedens virke, hvis hovedfund er, at tre fjerdedele af de borgere, der klagede til Politiklagemyndigheden i 2015-16, var utilfredse med den samlede behandling af klagen. Utilfredsheden bunder blandt andet i, at de klagendes ønsker til resultatet af klagen - hvor flertallet håber, at deres klage kan medvirke til at få politiet til at ændre adfærd fremadrettet - harmonerer dårligt med myndighedens primære opgave, som er at vurdere, om enkelte polititjenestemænd har handlet kritisabelt og/eller strafbart. Afslutningsvis diskuteres alternative muligheder for behandling af klager over politiet, herunder særligt mulighederne for genoprettende foranstaltninger.

\section{Baggrunden for etableringen af Den Uafhængige Politiklagemyndighed}

Politiklagemyndigheden blev etableret på en interessant baggrund - nemlig at der angiveligt var diskrepans mellem det hidtidige klagesystems faktiske funktion og oplevelsen af denne funktion. Klagesystemet, hvor Statsadvokaten efterforskede og vurderede klager under tilsyn fra Politiklagenævnet, fungerede efter Justitsministeriets mening udmærket - men der var genkommende kritik af, at dette klagesystem ikke i tilstrækkelig grad var uafhængigt af politiet. Som det hedder i kommissoriet for det udvalg, der skulle komme med forslag til nyt klagesystem:

»Overordnet set er det fortsat Justitsministeriets opfattelse, at den nuværende klageordning - og herunder statsadvokaternes samarbejde med politiklagenævnene - er velfungerende. Det er imidlertid meget væsentligt, at der også i befolkningen er tillid til, at sagerne i enhver henseende behandles sagligt og korrekt - og inden for rimelig tid (...) Udvalget skal i den forbindelse overveje, om det er muligt - inden for de overordnede rammer for den nuværende klageordning - $\mathrm{i}$ endnu højere grad at sikre offentlighedens tillid til, at sager vedrørende politiets personale behandles på betryggende vis« (Justitsministeriet, 2009:10).

Som det fremgår, skulle et eventuelt nyt system etableres inden for de overordnede rammer af den tidligere klageordning, og fornemmelsen af, at det ikke for alvor var tanken at ændre på klagesystemets funktion, forstærkes af folketingsdebatten i forbindelse med behandlingen af lovforslaget om etableringen af Politiklagemyndigheden. Her sagde Tom Behnke, ordfører fra Konservativt Folkeparti, følgende:

»Også Det Konservative Folkeparti kan støtte lovforslaget her, også selv om den eksisterende politiklageordning jo faktisk fungerer udmærket. Den gældende politiklageordning, altså den, der gælder i dag, kan jeg huske blev indført under SR-regeringen, og begrundelsen for, at man lavede den ordning, vi har i dag, var, at der efterhånden var manglende tillid til, at den gamle 
ordning fungerede. Dengang var man også enige om, at den gamle ordning sådan set var velfungerende, men tilliden var ved at vige, og derfor var man alene af den grund nødt til at lave en ny ordning, og det gjorde man så. Det er så den ordning, som vi har til debat i dag. Nu er det blevet den gamle ordning, som der er en vigende tillid til bredt set, hvilket så bevirker, at vi nu laver en ny ordning. Det er egentlig ikke, fordi den eksisterende ordning fungerer dårligt, det gør den ikke, men fordi det er vigtigt, at der er tillid til, at den ordning, vi har for klager over politiet, er velfungerende.

Så når vi nu ændrer systemet og indfører en helt ny uafhængig politiklagemyndighed, håber jeg, at vi den her gang får en længere levetid end for de forrige, for det, der har været en tendens til, er, at de her ordninger lever 10-12 år, og så, uanset om det er strengt nødvendigt at ændre den eller ej, ændrer man den, for så får vi ligesom rørt lidt rundt i gryden, og så får vi igen dialogen, vi får dialogen med borgerne, og vi får lavet et system, hvor vi alle sammen kan have tillid til hinanden« (Ordførertale, KF, 12/1 2010).

Man fristes til, med Fyrsten i romanen Leoparden (Tommasi di Lampedusa, 1959), at sige, at »alt må forandres, for at alt kan blive som det er«, hvilket også har vist sig at være tilfældet for de klagendes vurdering af sagsbehandlingen. Dette vender vi tilbage til efter en kort redegørelse for, hvad forskningen i øvrigt siger om politiklagesystemer.

\section{International forskning på politiklagesystemer}

Den overordnede konklusion på internationale erfaringer med politiklagesystemer er, at de ofte skuffer de klagende. Det skyldes blandt andet, at mange klagere ikke først og fremmest ønsker en formel afklaring af et skyldsspørgsmål (Landau, 1994), men derimod anerkendelse, en forklaring, en undskyldning eller forsikring om, at politiet fremadrettet vil handle anderledes. Da de fleste klagesystemer er fokuseret på at vurdere, om de indklagede politifolk kan pålægges et individuelt ansvar - hvilket kun sjældent bliver resultatet, for eksempel viser en undersøgelse fra Norge, at kun 6-8 pct. af klagerne fik medhold (Thomassen, 2002) - bliver mange klagere skuffede (Maguire \& Corbett, 1991). De, som klager, er også utilfredse med lange sagsbehandlingstider og manglende information om processens fremdrift. En senere undersøgelse fra Storbritannien (med en meget lav svarprocent og få besvarelser) viser en noget højere andel af klagere, som ønsker politifolkene straffet/irettesat, men viser også, at to tredjedele af de klagende ikke mener, de har nået målet med deres klage (Waters \& Brown, 2000).

Den generelle udvikling på området er gået i retning af klagesystemer, som er uafhængige af politiet, som samtidig inddrager repræsentanter for civilsamfundet i klagebehandlingen på den ene eller anden måde (Goldsmith, 1991; Prenzler, Mihinjac, \& Porter, 2013; Reiner, 2010; Savage, 2013). Her er de øvrige nordiske lande undtagelser: 
I Norge behandles mulige straffesager mod politipersonale af Spesialenheten for Politisaker (som er uafhængig af politiet, men fagligt underlagt Rigsadvokaten og administrativt underlagt Justisdepartementet), mens klager over politiets opgavehåndtering vurderes af politiet selv. Et omfattende udvalgsarbejde vedr. kontrol med politiet foreslog, at Spesialenhetens virke skulle udvides, således at den kom til at fungere som indgangsportal - et »servicetorg for politiklager« (NOU, 2009: 201) - men denne ændring er foreløbig ikke gennemført. I Sverige behandles mulige straffesager mod politipersonale af Avdelningen för Särskilda Utredningar, ${ }^{2}$ mens andre klager over politiet indgives til Justitieombudsmannen. I Finland undersøges mulige straffesager af Riksåklageren, mens såkaldt administrative klager behandles af den lokale politimyndighed/Polisstyrelsen. ${ }^{3}$ Klageordningerne ligner altså hinanden både derved, at der skelnes mellem mulige straffesager og andre klager, og ved, at der ikke er nogen civil deltagelse i behandlingen af klagesagerne.

Inddragelse af civilsamfundet i klageprocessen er dog ikke nogen garanti for øget tilfredshed - i USA fandt De Angelis (2009), at et nyt, uafhængigt klagesystem med civilt islæt nok øgede tilfredsheden med dele af klagebehandlingen, men at der ikke sås nogen ændringer i tilfredsheden med den samlede klagebehandling eller med resultaterne af klagen. Ligeledes i USA fandt en ældre undersøgelse (Walker \& Bumphus, 1992), at de fleste klagesystemer havde en eller anden form for civil repræsentation, men det var vanskeligt at sige noget præcist om, hvilken type system som var mest effektiv - blandt andet fordi det er vanskeligt entydigt at definere, hvad man skal forstå ved effektivitet i denne sammenhæng.

I de senere år er der i de engelsktalende lande gennemført flere forsøg med forskellige former for genoprettende tiltag/mediation i forbindelse med klager over politiet. Desværre er evalueringer af disse forsøg ofte præget af en meget lav svarprocent. I New York, for eksempel, fandt man, at såvel politifolk som klagere var mere tilfredse efter mediation, blandt andet fordi de klagende fik et bedre indtryk af, hvordan politiet så den konkrete hændelse (Bartels \& Silverman, 2005). Med en svarprocent blandt klagerne på 18, er det dog svært at tro, at besvarelserne er repræsentative. I Denver fandt Schaible m.fl. (2012) ligeledes, at klagere og politifolk, der havde deltaget i mægling, var mere tilfredse end dem, der havde deltaget i traditionel klagebehandling. Her var svarprocenten blandt klagere, der deltog i mægling, relativt høj, mens den var meget lav blandt klagere, der fik klagen behandlet på almindelig vis, hvilket kan tænkes at overdrive det positive resultat af mægling. 
I Storbritannien viste en undersøgelse foretaget af Hill m.fl. (2003), at halvdelen af de klagende var interesserede i en uformel behandling af klagen, men også, at en del af dem efterfølgende var skuffede over processen - hvor en overordnet polititjenestemand forestår en undersøgelse af klagen, og hvor klager og indklaget i nogle, men ikke alle, tilfælde mødes ansigt til ansigt. Hvor dette ikke sker, mødes klageren og den overordnede. En opfølgende undersøgelse, hvor man sammenlignede klagere, der havde deltaget i uformel behandling, med klagere, der havde fået klagen behandlet på almindelig vis, viste større tilfredshed med både klagehåndteringen og resultatet hos den første gruppe (Young m.fl. 2005).

Samlet set viser den internationale forskning, at der er stor utilfredshed blandt borgere, der klager over politiet, men også, at en uformel klagebehandling, herunder forskellige former for mægling, synes at give bedre resultater end traditionel behandling med fokus på vurdering af internationalt ansvar. Disse konklusioner er dog baseret på en række undersøgelser, der er præget af små populationer og lave svarprocenter.

\section{Introduktion til Den Uafhængige Politiklagemyndighed.}

Myndigheden er fysisk beliggende i Aarhus og er bemandet med egne jurister og efterforskere (som typisk har en fortid som politifolk). Den ledes af en direktør, som refererer til Politiklagerådet, som ledes af en landsdommer og har repræsentation af universitetsjurister og lægmænd. Myndigheden modtager alle typer klager over politiet, men sagsgangen er afhængig af, hvilken type klager der er tale om:

- Adfcerdsklager drejer sig om politiets måde at optræde på - f.eks. uhøflighed, nedladende sprogbrug mv. Sådanne klager undersøges og vurderes af Politiklagemyndigheden, og de kan, ifald myndigheden finder klagen berettiget, udløse kritik af varierende alvor over for de indklagede politifolk - som selv bliver hørt i forbindelse med sagsbehandlingen. Udtales kritik, følges denne typisk (men ikke altid) op af disciplinære sanktioner fra Rigspolitiet. Disse afgørelser kan ikke ankes.

- Notitssager er adfærdssager i den mindre alvorlige ende, som behandles uformelt af en overordnet fra den lokale politikreds. Klager får tilbud om en samtale med den overordnede, og indvilliger klager heri, træffer Politiklagemyndigheden ikke nogen formel afgørelse i sagen.

- Dispositionsklager drejer sig om politifaglige beslutninger - fra klager over, at politiet ikke yder assistance, når de bliver bedt om det, til klager over uberetti- 
get anholdelse/visitation. Denne type klager undersøges og vurderes af den lokale politidirektør og ikke af Politiklagemyndigheden (selv om mange klagere antager det).

- Straffesager drejer sig om eventuelt strafbare handlinger begået af politifolk. Disse efterforskes af Politiklagemyndigheden, som derefter indstiller til statsadvokaten, om der skal rejses tiltale. Afgørelsen er dog alene statsadvokatens.

- I sager om færdsel (f.eks. hastighedsoverskridelser), hvor de indklagede politifolk erklærer sig skyldige, overlades behandlingen til den lokale politidirektør.

Klagesystemet er således temmelig indviklet, og det kan af og til være vanskeligt at vurdere, f.eks. om en klage vedrører adfærd eller strafbar optræden, ligesom der kan indgå flere former for klager i den samme henvendelse. Som det vil fremgå nedenfor, er det også vanskeligt for mange klagende at forstå sagsgangen.

\subsection{Politiklagemyndighedens officielle statistik}

Efter overgangen fra statsadvokaten til Politiklagemyndigheden skete der en klar stigning i antallet af alle typer klagesager, som det fremgår af figur 1 .

Figur 1: Udviklingen i antallet af indkomne straffe-, adfcerds-og fcerdselssager mod politipersonale i perioderne 2002-2011 og 2012-2016. Undersøgelsessager indgår ikke. Kilder: Politiklagemyndigheden (2018); Rigsadvokaten (2012)

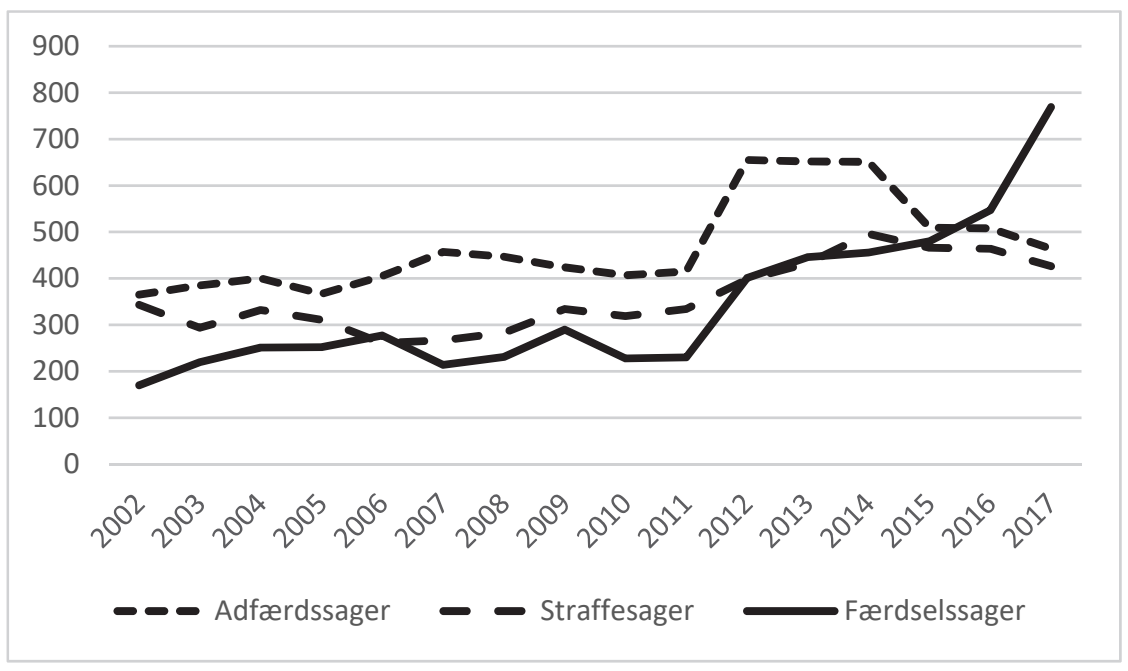


Det ses imidlertid også, at såvel adfærdsklager som straffesager i de sidste år har stabiliseret sig på et noget lavere niveau end i de første år af myndighedens levetid, om end det fortsat er højere, end det var i statsadvokatens periode. Den stærke stigning i antallet af færdselssager kan næppe tilskrives Politiklagemyndighedens etablering, den skyldes snarere en vækst i antallet af ATK-biler, ${ }^{4}$ som har medført en kraftig vækst $\mathrm{i}$ antallet af sigtelser for hastighedsoverskridelser - der er også en kraftig vækst blandt civile bilister.

Ser vi i stedet på de afgørelser, Politiklagemyndigheden (samt statsadvokaten) har truffet, fremgår det af tabel 1, at langt hovedparten af de indkomne klager ender, uden at klager får medhold.

Tabel 1: Sager, hvor Politiklagemyndigheden har truffet afgørelse 2012-2017, fordelt på sagskategorier* (Kilde: Politiklagemyndigheden, diverse år)

\begin{tabular}{|c|c|c|c|c|c|c|c|c|c|c|}
\hline & \multicolumn{2}{|c|}{ Straffesager } & \multicolumn{2}{|c|}{ Færdselssager } & \multicolumn{5}{|c|}{ Adfærdssager } & \multirow[t]{2}{*}{ I alt } \\
\hline & I alt & $\begin{array}{c}\text { Heraf } \\
\text { m. tilta- } \\
\text { le- } \\
\text { grund- } \\
\text { lag }\end{array}$ & I alt & $\begin{array}{l}\text { Heraf m. } \\
\text { tiltale- } \\
\text { grundlag }\end{array}$ & I alt & $\begin{array}{l}\text { Heraf } \\
\text { Foræl- } \\
\text { det/ til- } \\
\text { bage- } \\
\text { kaldt }\end{array}$ & $\begin{array}{l}\text { Heraf } \\
\text { For- } \\
\text { holdet } \\
\text { bekla- } \\
\text { get }\end{array}$ & $\begin{array}{l}\text { Heraf } \\
\text { m. kri- } \\
\text { tik }\end{array}$ & $\begin{array}{l}\text { Notits- } \\
\text { be- } \\
\text { hand- } \\
\text { let }\end{array}$ & \\
\hline 2012 & 173 & 7 & 305 & 56 & 288 & 32 & 9 & 16 & 233 & 999 \\
\hline 2013 & 418 & 12 & 461 & 84 & 436 & 34 & 14 & 22 & 279 & 1594 \\
\hline 2014 & 468 & 14 & 463 & 97 & 417 & 31 & 15 & 30 & 226 & 1574 \\
\hline 2015 & 490 & 17 & 345 & 63 & 333 & 32 & 11 & 21 & 183 & 1351 \\
\hline 2016 & 453 & 12 & 566 & 98 & 347 & 34 & 15 & 24 & 174 & 1540 \\
\hline 2017 & 412 & 12 & 429 & 56 & 268 & 23 & 16 & 17 & 164 & 1273 \\
\hline I alt & 2414 & 74 & 2569 & 454 & 2089 & 186 & 80 & 130 & 1259 & 8331 \\
\hline
\end{tabular}

* Kategorien »øvrige« er udeladt, da der er tale om et meget begrænset antal sager, som Politiklagemyndigheden tager op af egen drift.

** Antallet for 2012 er usædvanlig lavt, da dette var første år, myndigheden modtog klager.

Af de i alt 1903 adfærdsklagesager, ${ }^{5}$ Politiklagemyndigheden har behandlet til og med 2017, har myndigheden udtalt kritik i 130 sager, svarende til 6,8 pct. Medtages de sager, hvor myndigheden har udtalt en generel beklagelse af hændelsen (uden at udtale individuel kritik), har klager fået en form for medhold i lidt over hver tiende adfærdsklage. Dette er en noget højere »medholdsprocent «, end tilfældet var i statsadvokatens periode (2002-2011), hvor 3 pct. af klagerne endte med kritik, mens forholdet blev beklaget i 3,8 pct. af sagerne, altså en samlet 
medholdsprocent på 6,8. ${ }^{6}$ Politiklagemyndighedens medholdsprocent $\mathrm{i}$ adfærdsklagesager har været nogenlunde stabil i hele myndighedens levetid. Hvad straffesager angår, var der i statsadvokatperioden tiltalegrundlag i 3,5 pct. af klagerne - i Politiklagemyndighedens levetid har der været tiltalegrundlag i 3 pct. af klagerne, altså reelt set samme andel. Afgørelser i færdselssagerne kan, grundet de ændringer i hastighedskontrollen, som er nævnt ovenfor, ikke sammenlignes over tid. Hvad dispositionsklagerne angår, foreligger der slet ikke afgørelsesstatistik.

Samlet set kan det altså konstateres, at der ikke er sket nogen nævneværdig ændring af vurderingen af straffesager mod politiet, mens der er sket en fordobling $\mathrm{i}$ andelen af adfærdsklager, som ender med kritik af konkrete politifolk men andelen af sager, der fører til kritik, er stadig lav: omkring 1 ud af 15 sager.

\section{Evaluering af Politiklagemyndigheden}

Da Politiklagemyndigheden blev etableret, blev det samtidig besluttet, at dens virksomhed skulle evalueres efter nogle år. Hvad der nærmere skulle undersøges, var ikke præcist defineret, ud over at spørgsmålet om myndighedens uafhængighed og klagernes tillid til sagsbehandlingen skulle indgå. Den hidtidige forskning vedr. klagernes opfattelse af diverse politiklagesystemer var meget sparsom - der forelå kun en mindre undersøgelse blandt 110 klagere, som var udført til brug for udvalget bag betænkningen om den nye myndighed (Bjørnholt \& Jørgensen, 2008). I denne var der blandt andet stillet spørgsmål, om klagesystemet oplevedes som upartisk, samt om tilfredshed med sagsbehandlingstiden og den generelle tilfredshed med klagens behandling. For bedst muligt at kunne vurdere, om etableringen af Politiklagemyndigheden havde nogen effekt på oplevelsen af klagebehandlingen, blev det besluttet, at den nye evaluering så vidt muligt skulle tage udgangspunkt i den tidligere.

\subsection{Evalueringens metode}

Undersøgelsen blev foretaget som telefoninterview, og udgangspunktet var, at alle, der havde fået afgjort en klage over politiet i perioden august 2014-marts 2016, skulle have mulighed for at deltage. Dette viste sig dog at være mere vanskeligt end forventet, idet en del af klagerne var meget svære at komme i kontakt med. I alt havde 1597 personer indgivet mindst én klage i perioden, men af disse lykkedes det kun at komme i kontakt med 817 personer - først og fremmest fordi det ikke var muligt at finde telefonnummer til dem. Blandt de 817 lykkedes det at gennemføre interviewet med de 658, men den samlede svarprocent er relativt lav - 41 procent. $^{7}$ En bortfaldsanalyse (baseret på et begrænset antal registeroplysninger vedr. de klagende og alene gennemført på ag- 
gregeret niveau) viste, at unge, indvandrere/efterkommere, personer med lav indkomst og personer uden tilknytning til arbejdsmarkedet er underrepræsenterede i undersøgelsen. Grundet personbeskyttelseshensyn har det ikke været muligt at knytte baggrundsoplysninger til de enkelte besvarelser, og det er derfor vanskeligt at sige noget præcist om, hvordan skævhederne i udvalget af respondenter har påvirket undersøgelsen. Samlet set er det mest sandsynligt, at en højere svarprocent alt andet lige ville have resulteret $i$ en mere negativ vurdering af Politiklagemyndigheden end den, der fremstår i det følgende.

Ud over den kvantitative undersøgelse blev der gennemført en række personlige interviews - $21 \mathrm{i}$ alt - med klagere, der havde deltaget $\mathrm{i}$ undersøgelsen. Disse klagere var udvalgt på baggrund af deres besvarelser i hovedundersøgelsen, således at alle sagstyper var repræsenteret, ligesom såvel tilfredse som utilfredse klagere blev interviewet.

\section{Evalueringens hovedresultater}

Resultatet af evalueringen var for det første, at en stor del af de klagende syntes at være uvidende om, hvilken type klage det var, de havde indgivet, og hvem det var, der behandlede den. I en lang række sager var der ikke overensstemmelse mellem, hvad klager opgav som klagens type, og så de oplysninger, Politiklagemyndigheden havde om den pågældende klage. Mange respondenter angav, at deres klage vedrørte flere forskellige forhold, ligesom de var tilbøjelige til at mene, at deres klage drejede sig om politiets adfærd: Hvor Politiklagemyndigheden rubricerede 147 af de 658 sager som straffesager, mente de klagende selv, at det kun gjaldt 45 klager.

219 sager var af Politiklagemyndigheden rubriceret som dispositionsklager (som altså blev behandlet af politiet selv), men i 99 af disse mente respondenterne, at det var Politiklagemyndigheden, som behandlede klagen. Tilsvarende mente kun 50 af respondenterne, at de havde deltaget i notitssagsbehandling, mens det faktiske tal ifølge myndigheden var 115 (som altså slet ikke fik en formel afgørelse på deres klage). Kvinden i citatet nedenfor har således deltaget i notitssagsbehandling, uden at hun tilsyneladende har forstået dette:

»De ringede til mig nogle uger senere, og der havde de lyttet samtalen igennem (...) og så gav de mig ret i sagen. Så sagde de, at jeg også kunne gå et trin videre i sagen, fordi [betjenten] havde været så uhøflig (...) Jeg mener, at der var nogle grader i det, så jeg kunne gå til en eller anden anklager, men det ønskede jeg så ikke (...) jeg synes, at det var et rigtig fint forløb, og for det første er det rigtig fint, at man kan klage på den måde, og at de ligesom ringede til mig og gav mig ret.« 
Kun ganske få mente, at deres klage var afgjort af statsadvokaten/politidirektøren. Der er således ingen tvivl om, at klagesystemet for mange klagere opleves meget forvirrende.

Respondenterne er tillige blevet spurgt om, hvad de ønskede at få ud af klagen, se tabel 2.

Tabel 2: Respondenternes svar på spørgsmålet: »Hvad ønskede du at få ud af din klage? «-svar i procent ( $n=656$, der kunne gives mere end ét svar).

\begin{tabular}{lcc}
\hline & Antal & Pct. \\
\hline At sørge for, at politiet ændrede adfærd en anden gang & 375 & 57 \\
\hline $\begin{array}{l}\text { At gøre politiets ledelse opmarksom på, at der var foregået } \\
\text { noget forkert }\end{array}$ & 307 & 47 \\
\hline At de politifolk, der var involveret i episoden, blev irettesat & 228 & 35 \\
\hline At få en undskyldning fra politiet & 172 & 26 \\
\hline At de politifolk, der var involveret i episoden, blev straffet & 122 & 19 \\
\hline Andet & 91 & 14 \\
\hline At få en samtale med en overordnet fra politiet & 59 & 9 \\
\hline I alt & 1354 & \\
\hline
\end{tabular}

Blandt dem, der svarede »andet«, var de hyppigste ønsker at få erstatning samt at få annulleret en bøde/anden straf, de var blevet pålagt. Et genkommende tema i klagernes ønsker er en form for »systemkritik«: De ønskede med deres klage at medvirke til at korrigere politiets handlemåde fremadrettet, således at andre ikke skulle opleve det, de selv havde oplevet. Tre ud af fire respondenter nævnte dette som (en del af) motivet for at klage. ${ }^{8}$ Under halvdelen, 46 pct., ønskede individuelle politifolk straffet og/eller irettesat, og kun 12 pct. angav dette som det eneste, de håbede at få ud af klagen. Et genkommende svar var derimod, at respondenterne ønskede, at deres klage blev anerkendt:

»Jeg havde håbet for det første, at de fremadrettet måske ville komme med en undskyldning. Sige, at det var forkert, bare et eller andet (...) Det er lidt det, jeg forbinder DUP med, det er, at de siger, når politiet skal stramme op. Jeg mener ikke, betjentene behøver skulle blive fyret eller betale en masse erstatning, det havde været nok bare at sige, at det var forkert.«

Som det fremgik ovenfor, var den faktiske medholdsprocent lav - omkring 6 procent af klagerne i straffe- og adfærdsager fik en form for medhold. Der er dog en 
større andel af undersøgelsens respondenter, der selv oplevede at have fået medhold: 10 procent mente, at de havde fået medhold i straffe- og adfærdsklager. Inkluderes sager, der af Politiklagemyndigheden var rubriceret som dispositionssager eller notitssager, er det hele 18 pct. af respondenterne, der oplevede at få medhold. Dette skyldes først og fremmest, at en ret stor del af de respondenter, som har deltaget i notitssagsbehandling, oplevede, at samtalen endte med, at de fik medhold (selv om Politiklagemyndigheden altså ikke har truffet nogen formel afgørelse i disse sager).

Langt hovedparten af respondenterne mente selv, at det var Politiklagemyndigheden, der behandlede deres sag, og evalueringen har derfor lagt respondenternes egen vurdering til grund. Dette betyder, at en del af resultaterne reelt kan vedrøre politiets behandling af dispositionsklager. Med dette forbehold viser evalueringen, at 40 pct. af de adspurgte ikke oplevede, at Politiklagemyndigheden tog deres klage alvorligt. Ligeledes mente kun 22 pct., at myndigheden »gjorde, hvad den kunne, for at komme frem til en retfærdig afgørelse«, mens 67 pct. var uenige heri. 48 pct. kunne slet ikke forstå, hvordan afgørelsen i deres sag var blevet, som den var, og 73 pct. af respondenterne var utilfredse med den samlede behandling af deres klage. Samtidig var flertallet klar over, at der er tale om en uafhængig myndighed, men et lige så stort flertal - 58 pct. - mente, at myndigheden tog parti for politiet. Viden om myndighedens formelle uafhængighed følges altså ikke af en oplevelse af uafhængighed i sagsbehandlingen.

\subsection{Er det nye klagesystem bedre end det gamle - set med klagernes øjne?}

Der findes som tidligere nævnt en mindre undersøgelse af klagernes oplevelse af det tidligere klagesystem (Bjørnholt \& Jørgensen, 2008). En sammenligning mellem før og nu besværliggøres af, 1) at der var meget få respondenter i undersøgelsen fra 2008, 2) at der ikke indgår dispositionsklager i 2008-undersøgelsen, og 3) at ingen af respondenterne i 2008 oplevede at få medhold i deres klage.

Den begrænsede sammenligning, det trods alt er muligt at foretage, viser meget få forskelle mellem $2008 \mathrm{og}$ 2016. Andelen, som har svært ved at forstå, hvorfor afgørelsen blev, som den blev, er stort set lige stor, og det er i begge år omkring tre ud af fem, som er utilfredse med sagsbehandlingstiden. Til gengæld er der i 2016 væsentlig flere, som kender opbygningen af klagesystemet, og ved, at Politiklagemyndigheden er uafhængig. Da den generelle tilfredshed med sagsbehandlingen påvirkes af oplevelsen af medhold (som ingen respondenter havde i 2008), er der i stedet foretaget en sammenligning mellem respondenterne fra 2008 og de klagere, der i 2016 ikke oplevede medhold. Her viser sig en statistisk signifikant ${ }^{9}$ forskel: I 2008 var 40 pct. meget utilfredse med den samlede sagsbe- 
handling - i 2016 var andelen steget til 55 pct. ${ }^{10}$ En forsigtig konklusion er dermed, at den øgede andel af respondenter, som i 2016 ved, at Politiklagemyndigheden er uafhængig, ikke følges af en større tilfredshed med den samlede sagsbehandling - tværtimod.

\subsection{Hvad afhoenger tilfredsheden med sagsbehandlingen af?}

For nærmere at undersøge sammenhængen mellem den generelle tilfredshed med sagsbehandlingen og en række andre variable er der i evalueringen gennemført en række regressionsanalyser. De viser for det første, at det $i k k e$ betyder noget for tilfredsheden, om respondenten ved, at Politiklagemyndigheden er en uafhængig myndighed (dog er der flere utilfredse blandt den gruppe, som mener, at myndigheden er en del af politiet), ligesom det heller ikke spiller nogen betydende rolle, om respondenten ønskede politifolkene straffet eller irettesat.

Analysen viser fire signifikante sammenhænge:

- Blandt dem, der har oplevet medhold i klagen, er tilfredsheden større (70 pct.), end blandt dem, der ikke har (17 pct.)

- Blandt dem, der har forståelse for afgørelsen i sagen, er tilfredsheden større end blandt dem, der ikke har en sådan forståelse: Blandt dem, der har høj grad af forståelse, er 75 pct. tilfredse mod 5 pct. blandt dem, der slet ikke har forståelse for afgørelsen.

- Blandt dem, der er tilfredse med sagsbehandlingstiden, er den generelle tilfredshed større end blandt dem, der er utilfredse med sagsbehandlingstiden.

- Den stærkeste sammenhæng ses med spørgsmålet om, hvorvidt klagen blev taget alvorligt: blandt dem, der er helt enige heri, er 64 pct. tilfredse/meget tilfredse, mens 21 pct. er meget utilfredse med sagsbehandlingen under ét. Blandt dem, der er helt uenige i, at klagen blev taget alvorligt, er 2 pct. tilfredse med sagsbehandlingen, mens 90 pct. er meget utilfredse.

Efterfølgende er der foretaget yderligere analyser af, hvilke variable der hænger sammen med oplevelsen af at blive taget alvorligt. Her betyder det igen noget, om man har forståelse for afgørelsen, men her viser det sig også, at klagere, der ifølge Politiklagemyndighedens opgørelse har deltaget i notitssagsbehandling (uanset om de selv er klar over det eller ej), oftere oplever deres sag taget alvorligt.

Samlet set viser undersøgelsen nogle centrale pointer vedr. klager over politiet: 
- Hovedparten af de klagende ønsker at udtrykke kritik af politiet som institution, og de ønsker, at deres klage kan medvirke til, at politiet ændrer opførsel en anden gang

- Kun lige under halvdelen ønsker, at de konkrete politifolk, klagen omfatter, bliver irettesat eller straffet - og kun en ud af ni har alene dette mål med klagen.

- Omkring tre ud af fem, der klager til Politiklagemyndigheden, er klar over, at der er tale om en uafhængig institution - men samtidig mener tre ud af fem, at myndigheden i sin sagsbehandling tog parti for politiet. Tre ud af fire klagere er utilfredse eller meget utilfredse med behandlingen af deres sag, og tilfredsheden er blandt andet afhængig af sagsbehandlingstiden, forståelse for afgørelsen samt, først og fremmest, om klageren oplever, at klagen blev taget alvorligt - det gør 47 pct. af klagerne, mens 43 pct. er uenige.

Det er nærliggende at tolke resultatet på den måde, at en væsentlig motivation for mange klagere er, at de ønsker deres (negative) oplevelse med politiet anerkendt, ligesom de ønsker, at deres erfaringer skal medvirke til at forbedre politiets indsats.

\section{Om uafhængighed og anerkendelse}

I et studie af politiklagesystemer identificerer Stephen Savage (2012) tre mulige betydninger af uafhængighed (independence):

- Uafhængighed forstået som upartiskhed - klagebehandlingen er tilstræbt neutral og undgår at tage parti for nogen af parterne på forhånd.

- Uafhængighed som afstand - den klagebehandlende myndighed understreger sin uafhængighed af den ene part, nemlig politiet.

- Uafhængighed som objektivitet - klagebehandlingen søger sandheden og baserer sig alene på de tilgængelige fakta og ikke på nogen overordnet målsætning.

Som beskrevet ovenfor indgår de to første betydninger i svarene i undersøgelsen, men interessant nok trækker de ikke i samme retning: Halvdelen (51 pct.) af dem, der mener, at Politiklagemyndigheden er uafhængig, mener samtidig, at myndigheden har taget parti for politiet i den konkrete sag. At man er klar over, at myndigheden er formelt uafhængig, er altså ikke ensbetydende med, at man oplever den som upartisk. 
Den tredje form for uafhængighed er den, Politiklagemyndigheden selv lægger vægt på - myndighedens »motto«, som fremhæves på hjemmesiden og $\mathrm{i}$ myndighedens publikationer - er I sandhedens tjeneste. Det er kun et mindretal af klagerne, der synes at finde dette motto dækkende for deres oplevelse af klagebehandlingen - som beskrevet ovenfor, mener to ud af tre ikke, at Politiklagemyndigheden gjorde, hvad den kunne for at nå frem til en retfærdig afgørelse, og to ud af tre kan kun i ringe grad eller slet ikke forstå, at afgørelsen er faldet ud, som den er.

Størstedelen af adfærdsklagerne ender uden kritik af politipersonalet, og en del af disse sager er afgjort som »påstand mod påstand «. ${ }^{11}$ I sådanne sager får klager meddelelse om, at Politiklagemyndigheden ikke er i stand til at afgøre, om der er foregået noget kritisabelt, og klager kan dermed ikke få medhold. Nogle klagere opfatter dog en sådan afgørelse som udtryk for, at Politiklagemyndigheden ikke tror på deres version af begivenhederne. ${ }^{12}$ Som én siger: »Jeg læser den meget, som om at jeg lyver, den mail som jeg har fået.«

Nogle af de interviewede har desuden uopfordret nævnt, at det efter deres mening er svært at opfatte myndigheden som uafhængig af politiet, fordi hovedparten af de ansatte efterforskere er tidligere politifolk. Da der ikke er stillet spørgsmål herom i den kvantitative undersøgelse, kan det ikke vurderes, hvor udbredt denne kritik er.

Samlet set er det klart, at de negative holdninger til Politiklagemyndigheden i høj grad bygger på, at de klagende ikke føler, at deres oplevelse af hændelsesforløbet bliver anerkendt. Loader og Walker (2007) mener, at anerkendelse (recognition) $\mathrm{i}$ forholdet mellem borgere og politi har en vigtig funktion: Anerkendelse af alternative holdninger til, hvordan orden og sikkerhed opretholdes, kan medvirke til at undgå, at $/$ state actors procee[d] on the basis of their own self-defined and self-corroborating worldviews« (2007: 220), hvilket svarer ganske godt til de klagendes ønske om at påvirke politiet til at ændre praksis.

\section{Hvad mener politifolkene om klagesystemet?}

Som led i evalueringen er der foretaget interviews med en række politifolk, som har været indklaget for Politiklagemyndigheden. Det viste sig meget vanskeligt at få politifolk, der havde modtaget kritik fra myndigheden, i tale - flere svarede, at de intet godt havde at sige om Politiklagemyndigheden og derfor ikke ville deltage, mens hovedparten af de adspurgte slet ikke har svaret på henvendelser om interview. Dette afsnit bygger derfor primært på interviews og uformelle samtaler ${ }^{13}$ med politifolk, som har været indklaget, uden at de efterfølgende har modtaget kritik (eller er blevet tiltalt). 
Interviewene viser, at der fra politifolkenes side er fem hovedkritikpunkter mod Politiklagemyndigheden:

For det første klager mange over, at myndigheden foretager en indgående behandling af klager, der efter politifolkenes mening allerede fra starten burde afvises, fordi klagen er åbenbart grundløs. Det kan dreje sig om sager, hvor den klagende har medsendt videomateriale, som (efter indklagedes opfattelse) modbeviser påstandene i klagen. Der er også nævnt eksempler på, at politifolk har skullet afgive forklaring, selv om Politiklagemyndigheden ikke har foretaget nogen afhøring af den klagende, og eksempler på klager, hvor indholdet burde ligge under petitessegrænsen.

For det andet mener mange af de interviewede, at Politiklagemyndigheden har en egeninteresse $i$ at give medhold i klager. Logikken bag dette skulle være, at en myndighed, som udelukkende behandler klager over politiet, for at vise sig uafhængig må kunne fremvise et vist antal »succesfulde« sager. Denne vurdering opsummeres fint i følgende citat fra en indklaget:

»Det ser skidegodt ud, hvis de kan få en eller anden fyret, det ser godt ud i deres verden. Fordi hver gang de har en sag, og når de laver den der bog, når året er færdigt, hvis der så ikke står noget som helst, hvor der er nogen, der bliver fyret eller et eller andet, så er der jo på et eller andet tidspunkt nogen, der vil tænke: 'Hvorfor fanden spilder vi så vores penge på dem?’ Altså, de har incentive til lige at gå ud og få neglene i nogen.«

Denne kritik er mest rejst på et generelt plan - adspurgt om deres oplevelse af den konkrete efterforskning mod dem siger hovedparten, at de har oplevet den som fair.

For det tredje mener politifolkene, at det er helt forkert, at afgørelser i adfærdsklagesager ikke kan ankes. De mener, det forringer deres retsstilling og reelt stiller dem ringere end den øvrige befolkning.

For det fjerde kritiserer de Politiklagemyndighedens praksis i de straffesager, hvor statsadvokaten afviser at rejse tiltale, eller hvor den indklagede bliver frikendt i retten. I sådanne tilfælde kan myndigheden vurdere, at det - siden der ikke vurderes at være noget strafbart i den indklagedes handlemåde - bør undersøges, om denne giver anledning til kritik af den pågældendes adfærd. Dette opleves som en form for dobbeltstraf, som det fremgår i interviewuddraget herunder:

»Jeg blev frikendt i retten, og der er det jo så, at proceduren er ikke den samme for politifolk som for kriminelle i samfundet. Jeg blev frifundet i retten for den, men så valgte man så at lave den om til en adfærdsklage. Så der har man muligheden for, at kan man ikke blive straffet for det ene, så kan man blive straffet for det andet, og sådan er det jo ikke i den almindelige rets- 
praksis (...) den tankegang, det betyder for politifolk, at vi ikke har de samme rettigheder og retsstilling som andre i samfundet (...) du kan være sikker på, at hvis ikke de prøver det ene, så skal du nok være sikker på, at de prøver det andet.«

Netop denne praksis bidrager til tanken om, at Politiklagemyndigheden har en selvstændig interesse $\mathrm{i}$ at give medhold i så mange klager som muligt, jf. ovenfor.

For det femte kritiseres den ofte lange sagsbehandlingstid, ${ }^{14}$ som har konsekvenser for politifolkenes muligheder for f.eks. at skifte arbejde, ligesom det antages, at for mange verserende klagesager kan få betydning for, hvilke arbejdsopgaver de indklagede får lov at bestride under sagsbehandlingen:

»Jeg risikerer, at de siger til mig: 'Nej, nu har du simpelthen for mange, nu ryger du på kontor', fordi [Politiklagemyndigheden] er for lang tid om at behandle de klager, som måtte køre.«

Samlet set peger interviewene på, at Politiklagemyndigheden opleves som en slags fjendtlig institution, der så vidt muligt tager de klagendes parti, og som har en egeninteresse i, at klager ender med kritik af/straf til de indklagede politifolk. En del af de interviewede klager over, at de overhovedet er blevet genstand for undersøgelse, da de jo bare har passet deres arbejde - og de har fortalt, at der blandt deres kolleger hersker mistro til myndigheden samt bekymring for, hvad en eventuel klagesag kan betyde for deres fremtid i politiet. I Politiforbundet kan man godt genkende en del af ovenstående kritikpunkter, men kritikken er noget mere afdæmpet.

\section{Politiklagemyndigheden mellem klager og indklaget}

Er der én ting, der forener de borgere, der klager over politiet, og de politifolk, der bliver klaget over, er det oplevelsen af krænkelse. Borgerne føler sig krænkede over politiets opførsel, og en del af dem får efterfølgende forstærket denne oplevelse i og med, at de ikke får medhold i deres klage. Nogle synes at tolke det manglende medhold som udtryk for, at Politiklagemyndigheden mener, de lyver, selv om myndighedens afgørelse reelt går ud på, at man ikke kan afgøre, hvem der har ret. Hovedparten af de klagende mener, at myndigheden tager parti for politiet.

Omvendt oplever politifolkene det som krænkende, at Politiklagemyndigheden undersøger klager, som i politiets optik burde afvises med det samme; de oplever at myndigheden er på udkig efter det mindste fejltrin, og de føler sig frataget almindelige retsgarantier såsom mulighed for at anke kritik. 
Imellem disse to krænkede parter skal Politiklagemyndigheden navigere, og det er klart, at tiltag, der søger at imødekomme den ene part, kan virke negativt på den anden part: En grundig undersøgelse af selv de mindste forhold kan medvirke til, at de klagende oplever deres klager taget alvorligt, men den kan samtidig give grobund for, at de indklagede synes, at de bliver udsat for en urimelig behandling.

I sin nuværende opbygning spejler klagesystemet langt hen ad vejen det almindelige retssystem: målet er at vurdere, om der er beviser for, at individuelle politifolk har begået noget strafbart/kritisabelt, og både de klagende og de indklagede reduceres til bipersoner i sagsbehandlingen. Det er her værd at hæfte sig ved, at mange klagere har formål med deres klage, som rækker langt ud over vurderingen af det individuelle ansvar - de klager over politiet snarere end over enkelte politifolk. I denne sammenhæng kan det være formålstjenligt at anvende Trevor Jones' begreb om police accountability, et begreb, der er lidt svært at oversætte direkte, men som drejer sig om at stille politiet til ansvar: Jones (2008) skelner mellem at holde individuelle politifolk ansvarlige og at holde politiorganisationen ansvarlig. Hvor mange af klagerne synes at være optagede af at holde politiorganisationen ansvarlig, er klagesystemet fokuseret på at afklare, om der kan etableres et individuelt ansvar - samtidig med at mange klagesager er af en beskaffenhed, som gør denne opgave noget nær umulig. I de sager, hvor beviserne alene består af udsagn fra klager og indklagede, vil det typisk være meget vanskeligt at nå til anden afgørelse, end at man ikke kan afklare, hvem der har ret. Målsætningen er at arbejde i sandhedens tjeneste, men sandheden er i mange tilfælde umulig at fastslå - og dermed kommer myndighedens klagebehandling til at skuffe mange klagere, samtidig med at de indklagede oplever, at myndigheden netop tager parti for klagerne.

Spørgsmålet er så, hvad der kan gøres ved dette? Der er i udgangspunktet to overordnede tilgange til dette: den første er at overveje, om der kan ske forbedringer inden for det eksisterende system for behandling af klager over politiet, den anden er at vurdere, om selve systemet kan ændres i en retning, som fører til større tilfredshed hos klagere og indklagede?

\section{Kan man øge tilfredsheden i det nuværende system?}

Analysen af undersøgelsen blandt de klagende viste, at der er fire forhold, der påvirker tilfredsheden med klagebehandlingen:

For det første oplevelsen af medhold, for det andet klagerens forståelse for afgørelsen, for det tredje sagsbehandlingstidens længde, og endelig, om klageren oplever klagen taget alvorligt. Den foreliggende undersøgelse har ikke haft til formål at vurdere de konkrete afgørelser, Politiklagemyndigheden træffer, så det 
følgende tager udgangspunkt i, at myndighedens afgørelser er korrekte, når man tager det foreliggende bevismateriale i betragtning.

Den mest nærliggende mulighed for at påvirke såvel bevisbedømmelsen som klagerens forståelse for afgørelsen må være at forbedre grundlaget for afgørelsen - altså at skaffe et bedre bevismateriale, særligt i sager, hvor påstand står mod påstand. Dette kan i princippet ske ved, at politiet, i lighed med politiet i andre lande, forsynes med kropsbårne kameraer, som optager kontinuerligt. Optagelser fra sådanne kameraer vil give myndigheden et bedre grundlag at træffe afgørelser på - i de tilfælde, hvor der faktisk er foregået noget kritisabelt/strafbart, vil det kunne øge medholdsprocenten, mens det i de sager, hvor der ikke er foregået noget forkert, vil være lettere at forklare den klagende, hvorfor vedkommende ikke får medhold. Det er også muligt, at brugen af sådanne kameraer nedbringer antallet af klager (Ariel, Farrar, \& Sutherland, 2015; Ariel et al., 2017), ligesom der er tegn på, at de kan reducere omfanget af modstand mod politiet (Jennings m.fl. 2017), men dette er omdiskuteret (Ariel et al., 2016). Man kan forudse afledte problemer i de tilfælde, hvor kameraudstyret ikke virker (eller bevidst er blevet slukket), og det er i sagens natur vanskeligt at vurdere, om brugen af sådanne kameraer vil ændre væsentligt på andelen af klager, som får medhold.

Hvad sagsbehandlingstiden angår, kan det tænkes, at øgede bevillinger til myndigheden kan reducere denne (det er i sommeren 2018 besluttet at tilføre Politiklagemyndigheden yderligere midler), ${ }^{15}$ men hvor stor en effekt dette vil have på klagernes vurdering af myndigheden, kan ikke vurderes på forhånd.

Tilbage står spørgsmålet om, hvordan man kan øge de klagendes oplevelse af at blive taget alvorligt. Her kan der peges på to ting: For det første er klagere, der har deltaget i notitssagsbehandling, mere tilbøjelige til både at være tilfredse og at opleve deres klage taget alvorligt, så man kan overveje, om det er muligt at øge andelen af klager, som behandles på denne måde. For det andet kan man overveje, om man ved selve modtagelsen af klagen kan gøre mere ud af at finde ud af, hvad den klagende ønsker at få ud af sin klage - fra andre myndigheder findes eksempler på, at en sådan tilgang har reduceret antallet af klager, der sendes videre til formel behandling, samtidig med at de klagendes tilfredshed øges (Styrket borgerkontakt, 2012).

\section{En anden målsæetning for klagesystemet?}

En mere radikal løsning vil være at ændre målsætningen for Politiklagemyndighedens arbejde: Mindre vægt på afklaring af individuelt ansvar, større vægt på klagernes ønsker om at blive taget alvorligt og at bidrage til at holde politiorganisationen ansvarlig. Dette kunne for eksempel ske i form af en slags mægling eller 
mediation mellem klagere og indklagede. Som det er fremgået, giver notitsbehandling mere tilfredse klagere, selv om der ikke her er nogen direkte kontakt mellem klageren og den/dem, han/hun klager over. Den internationale forskning vedr. mediation i politiklagesager er foreløbig begrænset, både hvad angår omfang og videnskabelig styrke, men der findes, som beskrevet i afsnit 3 ovenfor, positive erfaringer at trække på. De politifolk, der er interviewet til den foreliggende undersøgelse, har haft forskellige opfattelser af, hvorvidt en model for mediation i klagesager er mulig, men det er langt fra alle, der er afvisende.

Faktisk nævnes det i betænkning 1507 om behandlingen af klager over politiet, at der bør gennemføres et forsøg med mægling i mindre alvorlige adfærdsklagesager, og Politiklagemyndigheden har sendt udkast til et sådant forsøg i høring, men det har foreløbig vist sig meget vanskeligt. Det skyldes først og fremmest spørgsmålet om, hvad der vil ske i det tilfælde, at en mægling gennemføres, men at klager er utilfreds med forløbet. Her mente Justitsministeriet, at man ikke kunne afskære den klagende fra at forlange klagen behandlet af Politiklagemyndigheden, hvilket ifølge Rigspolitiets høringssvar ${ }^{16}$ har den konsekvens, at man ikke kan sikre, at oplysninger fremkommet i forbindelse med mægling ikke vil kunne indgå i den efterfølgende klagebehandling. Der findes heller ikke lovhjemmel til at fritage politifolk fra disciplinære følger på baggrund af den slags oplysninger. Kort sagt: Deltager politifolk i en form for mægling, kan de risikere, at oplysninger givet i denne forbindelse ender med at blive brugt mod dem senere. Det er derfor forståeligt, at Politiforbundet ikke kan støtte op om et sådant forsøg, så længe lovgivningen er, som den er. I reglerne om notitssagsbehandling, som blev udarbejdet af udvalget, står følgende:

$\S 1019 \mathrm{k}$, stk. 3. Indhentes der som led i notitssagsbehandling en udtalelse fra indklagede, kan der ikke efterfølgende pålægges den pågældende disciplinæransvar for det eller de forhold, som indgår i notitssagsbehandlingen.

I betænkning 1507 fremgår det af afsnit 11.2.2.2, at en tilsvarende regel bør gælde ved konfliktmægling, men da udvalget ikke forestiller sig, at mægling kan blive en mere udbredt løsning, finder man

»derfor ikke grundlag for i retsplejeloven at foreslå særlige regler for konfliktmægling i politiklagesager, men skal pege på, at det vil være en mulighed, at der i en ny uafhængig politiklagemyndighed etableres en forsøgsordning med egentlig konfliktmægling « (Justitsministeriet 2009: $163)$. 
Udvalget bag betænkning 1507 synes således ikke at have overvejet spørgsmålet om, hvordan en forsøgsordning skulle kunne gennemføres, hvis den relevante lovgivning ikke er på plads, og det er vanskeligt at se, hvordan en forsøgsordning kan sættes i værk på det foreliggende grundlag.

Det er i denne sammenhæng væsentligt at anerkende, at mediation i forbindelse med politiklager langtfra er uproblematisk. Selv om de begrænsede internationale erfaringer synes overvejende positive, er der en række forhold, som bør medtænkes, hvis en sådan ordning skal kunne fungere:

For det første må det overvejes, hvilke sagstyper der skal indgå, og om en gennemført mediation skal kunne afslutte en sag også i de (få) tilfælde, hvor sagen ellers kunne have fået disciplinære eller strafferetlige følger? Det forekommer oplagt, at der må etableres en grænse for, hvilke sager der overhovedet kan indgå, men eftersom langt hovedparten af også de mere alvorlige klager ender, uden at der kan pålægges et individuelt ansvar, er det vanskeligt at vurdere, om en del af disse burde indgå i en form for mægling, på trods af at de potentielt (men ikke sandsynligt) kunne ende med straf til politifolkene. I modsat fald vil mediation kun blive aktuelt i meget få sager, og dermed ikke kunne påvirke de klagendes tilfredshed væsentligt.

For det andet må det overvejes, hvordan man skal behandle de sager, hvor den klagende part ikke ønsker at indgå i mediation. To klager med nogenlunde samme faktuelle indhold kan tænkes at blive behandlet temmelig forskelligt, hvis den klagende parts vilje til medvirken i en mediationsproces skal være afgørende hvilket igen vil give de indklagede politifolk en forskellig retsstilling.

For det tredje bliver det nødvendigt at overveje, hvilke særlige krav der stilles til en mediationsproces mellem to parter, som i udgangspunktet er stillet forskelligt. Politifolk, som handler i embeds medfør, kan netop være tvunget til at handle på embedets vegne, også i situationer, hvor ingen af de tilgængelige handlemuligheder er optimale. Det er derfor tænkeligt, at det også i en mediationsproces kan ske, at det bliver vanskeligt at skelne mellem individuelt og organisatorisk ansvar, samtidig med at det alene er den individuelle politiansatte, som indgår i processen.

Samlet set er mægling mellem klagere og politifolk altså næppe nogen mirakelkur, men henset til den store utilfredshed med det nuværende system, som findes blandt både klagere og indklagede, synes der at være god grund til i det mindste at overveje, hvordan en sådan proces kunne etableres. 


\section{Konklusion: Fra sandhedens til forståelsens tjeneste?}

Afslutningsvis kan man spørge, hvad der er den overordnede konklusion om Politiklagemyndighedens virke? En sådan konklusion må afhænge af, hvad målet med etableringen af myndigheden var. Hvis målet alene var at skabe en myndighed, der i befolkningens øjne var uafhængig af politiet, er det både lykkedes og mislykkedes, i hvert fald bedømt ud fra, hvad de adspurgte klagere mener: Et flertal ved, at myndigheden er uafhængig, men et lige så stort flertal mener, at myndigheden har taget parti for politiet i behandlingen af deres klage. Hvis målet var at gøre flere klagere tilfredse med behandlingen af deres klage, er det ikke lykkedes: Tre ud af fire klagere er utilfredse eller meget utilfredse, hvilket er mindst lige så mange som i en tidligere undersøgelse af ordningen med Politiklagenævn. Til gengæld synes iværksættelsen af notitssagsbehandling at være en succes - klagere, der har deltaget i denne type klagebehandling, er generelt mere tilfredse og føler sig taget alvorligt i højere grad end klagere, hvis klager er afgjort af Politiklagemyndigheden.

Det er svært at se, hvordan klagernes tilfredshed kan øges markant i det nuværende klagesystem. Borgere, der klager over politiet, har forskellige mål med klagen, men det er tydeligt, at de mål, hovedparten af klagerne angiver at have haft med deres klage - at holde politiorganisationen ansvarlig og fremadrettet at påvirke politiet $\mathrm{i}$ en positiv retning - harmonerer dårligt med myndighedens mål, som primært er at vurdere, om der kan gøres et individuelt ansvar gældende over for enkelte politifolk. For de indklagede politifolk må tilskyndelsen til at lære noget af en klage formodes at være begrænset; klagebehandlingen er binær af natur - man er enten taber eller vinder. Klagesystemet er dermed dårligt egnet til at skabe læring i organisationen.

Hvis der for alvor skal ske en udvikling i forholdet mellem de klagende borgere og det politi, de klager over, kommer man næppe uden om at ændre den grundlæggende præmis for klagesystemet, som i højere grad må arbejde i forståelsens tjeneste. Vægten skal bort fra det individuelle ansvar og over mod det institutionelle ansvar. Det må gøres muligt at afprøve konfliktmægling og/eller andre former for konflikthåndtering i de sager, hvor parterne indvilliger heri, og hvor indholdet af klagen ikke er så alvorligt, at det vil være åbenlyst urimeligt. Selv om en sådan tilgang næppe vil vende fuldstændig op og ned på de klagendes vurdering af klagesystemet, vil det være nærliggende at tro, at det på sigt vil skabe forbedringer. Det er i hvert fald et forsøg værd. 


\section{Noter}

1. Den foreliggende artikel bygger på den samlede evalueringsrapport (Holmberg, 2017), men videreudvikler en del af analysen, blandt andet baseret på (Holmberg, I review). Statistiske oplysninger om Politiklagemyndighedens arbejde er opdateret til de senest tilgængelige.

2. https://polisen.se/om-polisen/sarskilda-utredningar/ (tilgået 27/9 2018).

3. https://www.poliisi.fi/kundservice/synpunkter_och_kommentarer_om_polisens_verksamhet (tilgået 27/9 2018).

4. ATK betyder Automatisk Trafik Kontrol.

5. Forældede og tilbagekaldte sager er ikke medregnet.

6. Grundet pladshensyn er det ikke muligt her at gengive alle mellemregninger og kilder. Her henvises til selve evalueringen (Holmberg 2017).

7. En svarprocent på 41 er relativt høj, når der sammenlignes med internationale undersøgelser af politiklagesystemer, men ikke, når der sammenlignes med f.eks. de nationale offerundersøgelser, som gennemføres i regi af Justitsministeriet.

8. Respondenter, der har angivet, at de »ønskede at gøre politiets ledelse opmærksom på, at der var foregået noget forkert« og/eller at »de ville sørge for, at politiet ændrede adfærd en anden gang $\ll$.

9. $\mathrm{p}<0,01$.

10. Heri indgår alene straffe- og adfærdssager.

11. Hvor stor en andel af sagerne uden kritik, som er afgjort som påstand mod påstand fremgår ikke af myndighedens årsberetninger, men det drejer sig formodentlig om en ikke uvæsentlig del af sagerne.

12. Dette på trods af, at myndigheden angiveligt gør, hvad den kan for at gøre det klart, at man reelt blot mener, det er umuligt at afgøre, hvem der har ret.

13. På grund af vanskelighederne med at finde relevante informanter har jeg taget emnet op $i$ forskellige sammenhænge, blandt andet ved et møde med en række af politiets tillidsmænd. Jeg har ligeledes interviewet repræsentanter for Dansk Politiforbund. De fleste eksempler på sager er nogle, de interviewede selv har oplevet, men der er også eksempler på sager, de interviewede har hørt om - og hvor det derfor kan være sværere at afgøre, om sagens omstændigheder er korrekt gengivet.

14. Det hører med til vurderingen af denne kritik, at mange politifolk - angiveligt grundet mistillid til Politiklagemyndigheden - vælger at rejse til Aarhus, hvis de skal afhøres (frem for at afgive et skriftligt vidnesbyrd eller lade sig videoafhøre). Denne praksis medvirker til at forlænge sagsbehandlingstiden.

15. https://www.dr.dk/ligetil/justitsminister-lover-flere-penge-til-politiets-klagesystem, tilgået 19. juni 2018

16. Dateret 1. juni 2015. 


\section{Litteratur}

Ariel, B., Farrar, W.A., \& Sutherland, A. (2015). The effect of police body-worn cameras on use of force and citizens' complaints against the police: A randomized controlled trial. Journal of Quantitative Criminology, 31(3), 509-535.

Ariel, B., Sutherland, A., Henstock, D., Young, J., Drover, P., Sykes, J., ... Henderson, R. (2016). Report: increases in police use of force in the presence of body-worn cameras are driven by officer discretion: a protocol-based subgroup analysis of ten randomized experiments. Journal of Experimental Criminology, 12(3), 453-463. doi:10.1007/s11292-0169261-3

Ariel, B., Sutherland, A., Henstock, D., Young, J., Drover, P., Sykes, J., Henderson, R. (2017). »Contagious Accountability«. Criminal Justice and Behavior, 44(2), 293-316. doi:doi:10.1177/0093854816668218

Bartels, E.C., \& Silverman, E.B. (2005). An Exploratory Study of the New York City Civilian Complaint Review Board Mediation Program. Policing: An International Journal of Police Strategies and Management, 28, 619-630.

Bjørnholt, B., \& Jørgensen, C. (2008). En brugerundersøgelse af politiklagesystemet. aalborg: Aalborg Universitet.

De Angelis, J. (2009). Assessing the Impact of Oversight and Procedural Justice on the Attitudes of Individuals Who File Police Complaints. Police Quarterly, 12(2), 214-236. doi:10.1177/1098611109332425

Goldsmith, A.J. (1991). Complaints against the police: The trend to external review: Clarendon Press Oxford.

Hill, R., Cooper, K., Hoyle, C., \& Young, R. (2003). Introducing Restorative Justice to the Police Complaints System: Close Encounters of the Rare Kind. Oxford: Centre for Criminological Research, University of Oxford.

Holmberg, L. (2017). I forståelsens tjeneste? En evaluering af Den Uafhaengige Politiklagemyndighed. København: Justitsministeriet.

Holmberg, L. (I review). In service of the truth? An evaluation of the Danish Independent Police Complaints Authority.

Jennings, W.G., Fridell, L.A., Lynch, M., Jetelina, K.K., \& Reingle Gonzalez, J.M. (2017). A Quasi-Experimental Evaluation of the Effects of Police Body-Worn Cameras (BWCs) on Response-to-Resistance in a Large Metropolitan Police Department. Deviant Behavior, 38(11), 1332-1339. doi:10.1080/01639625.2016.1248711

Jones, T. (2008). The Accountability of Policing. In T. Newburn (Ed.), Handbook of Policing (pp. 693-724). London: Routledge.

Justitsministeriet. (2009). Betænkning om behandling af klager over politiet (Vol. 1507).

Landau, T. (1994). Public complaints against the police: A view from complainants: Centre of Criminology, University of Toronto Toronto.

Loader, I., \& Walker, N. (2007). Civilizing security: Cambridge University Press.

Maguire, M., \& Corbett, C. (1991). A study of the police complaints system: HM Stationery Office London.

NOU. (2009). Et ansvarlig politi. Åpenhet, kontroll og læring (Vol. 2009: 12).

Politiklagemyndigheden. (2018). Arsberetning 2017. Aarhus: Den Uafhængige Politiklagemyndighed. 
Prenzler, T., Mihinjac, M., \& Porter, L.E. (2013). Reconciling stakeholder interests in police complaints and discipline systems. Police Practice \& Research, 14(2), 155-168. doi:10.1080/15614263.2013.767095

Reiner, R. (2010). The Politics of the Police. Oxford: Oxford University Press.

Rigsadvokaten. (2012). Rigsadvokatens beretning 2010 og 2011. Behandling af klager over politiet. København.

Savage, S.P. (2012). Thinking independence: Calling the police to account through the independent investigation of police complaints. British Journal of Criminology, 53(1), 94-112.

Savage, S.P. (2013). Seeking 'Civilianness' Police Complaints and the Civilian Control Model of Oversight. British Journal of Criminology, 53(5), 886-904.

Schaible, L.M., Angelis, J.D., Wolf, B., \& Rosenthal, R. (2012). Denver's Citizen/Police Complaint Mediation Program. Criminal Justice Policy Review, 24(5), 626-650. doi: $10.1177 / 0887403412455327$

Styrket borgerkontakt, s. f. (2012). Rapport om forsøg med Styrket Borgerkontakt. En proaktiv, løsningsorienteret metode til håndtering af klager. København: Viemose forhandlingsrådgivning.

Thomassen, G. (2002). Investigating complaints against the police in Norway: An empirical evaluation. Policing and Society, 12(3), 201-210.

Tommasi di Lampedusa, G. (1959). Leoparden. København: Gyldendal.

Walker, S., \& Bumphus, V.W. (1992). The effectiveness of civilian review: Observations on recent trends and new issues regarding the civilian review of the police. Am. J. Police, 11, 1.

Waters, I., \& Brown, K. (2000). Police complaints and the complainants' experience. British Journal of Criminology, 40(4), 617-638.

Young, R., Hoyle, C., Cooper, K., \& Hill, R. (2005). Informal resolution of complaints against the police. Criminal Justice, 5(3), 279-317. doi:10.1177/1466802505055837 